\title{
Persoalan Corpus Delicti dalam Teologi Kristen tentang Persidangan Ilahi
}

\author{
Sonny Eli Zaluchu
}

Sekolah Tinggi Teologi Baptis Indonesia, Semarang, Jawa Tengah

gloryofgodmin@gmail.com

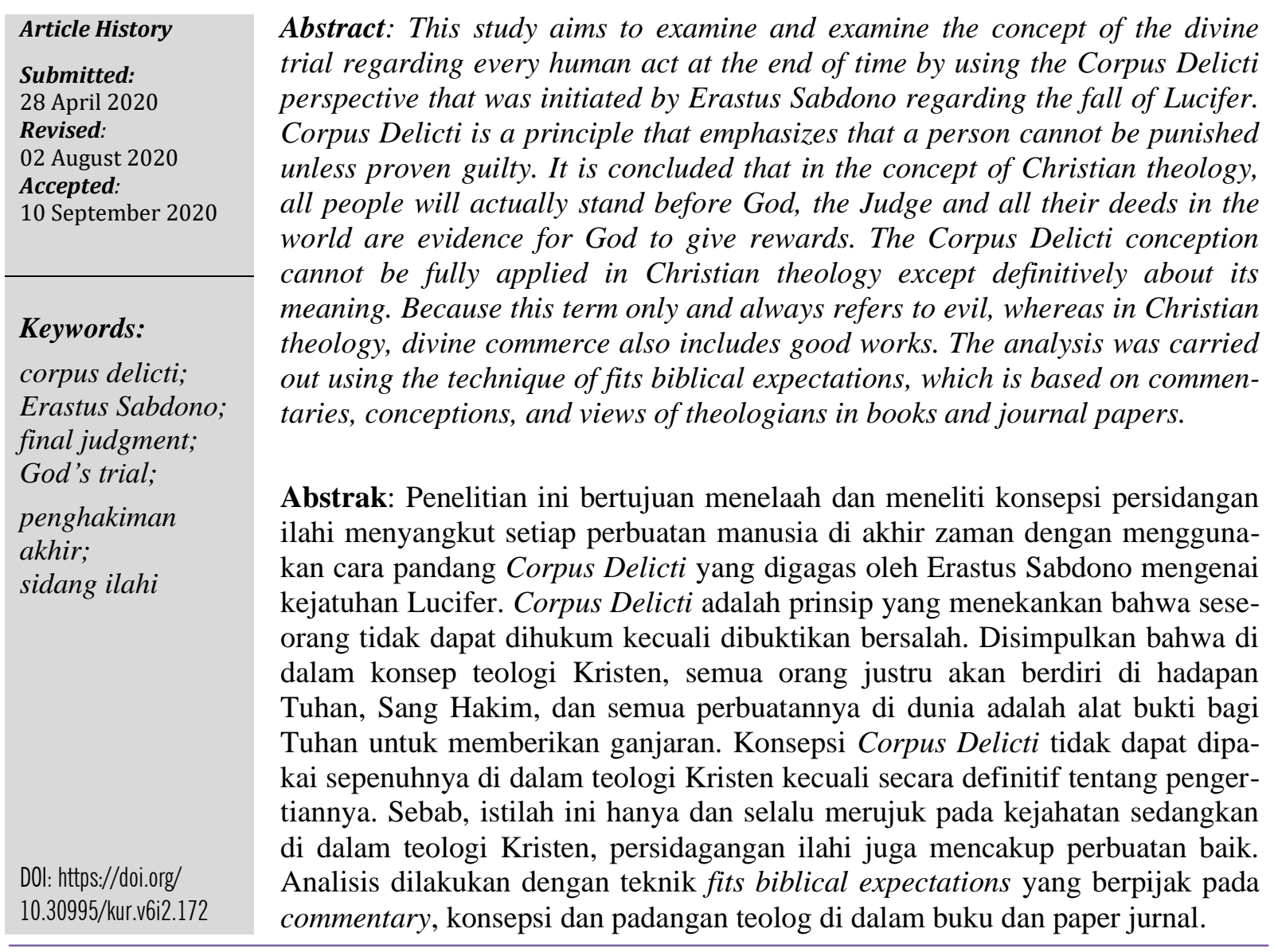

\section{Pendahuluan}

Pembuktian di dalam sebuah tindak kriminalitas, adalah alat yang sangat penting. Melalui bukti, seseorang dapat disangka dan didakwa, dimulai dari penyelidikan hingga di depan persidangan, untuk menentukan apakah seseorang telah melakukan tindakan atau perbuatan pidana. Bukti dapat menguatkan status seseorang apakah dianggap bersalah dan dihukum, atau sebaliknya, dibebaskn dan dipulihkan nama baiknya. Menurut Yustia, persoalan pembuktian adalah salah satu masalah pelik di dalam setiap usaha penegakan hukum, untuk menjerat pelaku tindak pidana. Dalam penelitiannya tentang pelaku kriminal mayantara (cyber crime), Yustia mengungkapkan tantangan dan beratnya usaha pembuktian, karena sifat kejahatan mayantara tergolong rumit, kompleks, sangat spesifik, dan melibatkan pendapat para pakar. Demikian juga di dalam tindak pidana umum. Hasil penelitian Suisno menyimpulkan bahwa selesai tidaknya suatu kasus pidana, sangat bergantung pada hasil pemeriksaan Hakim di 
persidangan khususnya relevansi terdakwa dengan bukti-bukti yang ada. Di antara sejumlah alat bukti yang dapat dipergunakan dalam penyelesaian perkara pidana tersebut, keterangan saksi adalah salah satu yang dapat menguatkan ataupun melemahkan. Oleh karena itu, berdasarkan kedua penelitian tersebut di atas, dapat disimpulkan bahwa pembuktian dan atau alat bukti, mengambil peran kunci di dalam sebuah konteks persidangan, yang berujung pada vonis, apakah seseorang dinyatakan bersalah atau tidak. Dengan kata lain, merupakan perkara yang tidak mudah dilakukan, untuk menyatakan status kebersalahan seseorang.

Sistem pengadilan di Barat mengenal sebuah konsep yang dinamakan Corpus Delicti. Menurut Flora Dianti di dalam Klinik Hukum Online, sebuah Corpus Delicti atau Corpora Delicti mencakup: Barang-barang yang menjadi sasaran tindak pidana; Barang-barang yang terjadi sebagai hasil dari tindak pidana (corpora delicti); Dan barang-barang yang pada umumnya dapat dipergunakan untuk memberatkan atau meringankan kesalahan terdakwa (corpora delicti). Ada pun barang-barang yang dipergunakan untuk melakukan tindak pidana tergolong ke dalam instrumenta delicti. ${ }^{1}$ Sehingga Corpus Delicti menjadi prinsip untuk berpijak apakah seseorang dapat dihukum karena berkenaan, atau dibebaskan karena tidak berkenaan, sebuah tindak pidana kejahatan tertentu di pengadilan.

Sebagaimana konsep pengadilan di dunia, ajaran kristen juga mengenal sistem pengadilan yang disebut pengadilan ilahi. Jika pengadilan di dunia untuk memutuskan apakah seseorang dinyatakan sebagai pelaku kejahatan atau tidak, maka pengadilan ilahi fokus pada semua pengadilan atas seluruh perbuatan manusia selama hidup di dunia. Di dalam Wahyu dikatakan, bahwa Tuhan bertindak memberikan pembalasan kepada setiap orang menurut perbuatannya (Why. 2:23). Konsep ini menempatkan seluruh orang percaya untuk dihakimi menurut standar pengadilan ilahi, pada akhirnya. Sebagaimana yang dikatakan Craig Keener, "Judgement according the one's works fits biblical expectations." Artinya, penghakiman tersebut menjadi konsep eskatologis, berkaitan dengan sebuah final judgement yang sudah pasti di akhir zaman.

Beberapa pernyataan di dalam Alkitab telah secara tegas memberi peringatan (warning) bahwa perbuatan apa pun di dunia ini, akan diadili dan akan menjadi alat bukti yang telah tercatat dihadapan Tuhan sang Hakim Agung. Oleh sebab itu, setiap orang dituntut menjaga perbuatannya selama menjalani hidupnya di bumi. Mengapa demikian? Setiap perbuatan manusia dapat dikategorikan sebagai alat bukti yang kelak akan memberatkan atau meringankan dakwaannya di hadapan Tuhan, saat memasuki sistem pengadian ilahi. Perbuatan tersebut menjadi sebuah Corpus Delicti yang menjadi dasar upah atau hukuman yang diterima seseorang dari Tuhan, Sang Maha Hakim.

Membawa konsep Corpus Delicti dalam persepektif eskatologis menjadi topik perbincangan para teolog dan praktisi rohani di Indonesia akhir-akhir ini. Argumentasi pro dan kontra mewarnai setiap pandangan, setelah kemunculan sebuah buku berjudul Corpus Delicti Hukum Kehidupan, yang ditulis oleh Erastus Sabdono, seorang teolog yang juga praktisi

${ }^{1}$ Flora Dianti, “Apa Perbedaan Alat Bukti Dengan Barang Bukti?,” Hukum Online, last modified 2011, accessed April 27, 2020, https://www.hukumonline.com/klinik/detail/ulasan/lt4e8ec99e4d2ae/apa-perbedaanalat-bukti-dengan-barang-bukti-/.

${ }^{2}$ Craig S. Keener, The IVP Bible Background Commentary - New Testament, 2nd ed. (Downer s Grove, Illionis: IVP Academic, 2014), 735. 
rohani. Buku itu sendiri sudah ditulis empat tahun yang lalu. Paper ini, bertujuan untuk menelaah konsep Corpus Delicti yang dimaksudkan oleh Sabdono, dan posisinya di dalam konstruksi teologis serta kehidupan kristiani. Dalam hal ini, penulis akan menggunakan konsep Keener tentang fits biblical expectations untuk mengkritisi hal-hal apa dari konsep tersebut yang sesuai dan yang tidak sesuai menggunakan perbandingan.

\section{Metode Penelitian}

Tulisan ini menggunakan metode review literature seperti dimaksud oleh $\mathrm{Hum}^{3}$, dan Denny \& Tewksbury. ${ }^{4}$ Konsep fits biblical expectations berpijak usaha mengkritisi apakah konsep yang diajukan (corpus delicti) dapat disejajarkan secara konseptual ke dalam pokok-pokok teologis. Langkah pertama adalah menelaah konsep dasar Corpus Delicti dalam domain hukum. Langkah kedua adalah mendeskripsikan pemikiran Sabdono di dalam usahanya mensejajarkan konsep Corpus Delicti dengan pengadilan Ilahi. Konsep-konsep mengenai biblical expectations dilakukan secara deskriptif dengan bertumpu pada beberapa commentary dan sumber-sumber primer lainnya seperti Alkitab, buku dan jurnal. Pada bagian kesimpulan, penulis melakukan fit of concepts dari Corpus Delicti ke dalam teologi Kristen menyangkut penghakiman akhir.

\section{Hasil dan Pembahasan}

\section{Istilah Corpus Delicti dalam Perspektif Hukum}

Corpus Delicti adalam bahasa Latin dapat diterjemahkan harafiah sebagai tubuh kejahatan (body of crime). ${ }^{5}$ Yang dimaksud dengan tubuh di sini adalah alat bukti dan fakta-fakta yang mendukung bahwa pada tubuh yang dimaksud, suatu kejahatan telah dilakukan. Dalam penggunaan yang populer, Corpus Delicti dapat mengacu pada objek fisik aktual yang menjadi dasar kejahatan. Dalam kasus pembakaran, itu akan menjadi bangunan yang hancur; dalam kasus pembunuhan, mayat korban. Sehingga Mirriam-Webster mendefinisikan istilah ini sebagai "the substantial and fundamental fact necessary to prove the commission of a crime and the material substance (such as the body of the victim of a murder) upon which a crime has been committed." Mengacu pada konsep tersebut, maka sebuah Corpus Delicti disebut demikian jika tersedia sebuah fakta substansial, dan materi substansial, yang dapat membuktikan kejahatan telah terjadi. Dalam hal ini sebuah kasus kejahatan hanya dapat dibawa kepengadilan jika telah cukup bukti mengenai cedera hukum dan agen atau pelaku kriminal.

Menurut Flynn, cidera hukum adalah kerugian yang ingin dicegah oleh hukum, seperti kematian, perampasan harta benda, atau pembakaran harta benda. Sementara agen kriminal adalah fakta bahwa kerugian itu disebabkan oleh tindak pidana beberapa orang. Dalam kasus pembakaran bangunan misalnya, menurut Flynn, bukti harus kuat dan memperlihatkan bahwa telah terjadi pembakaran bangunan atau properti yang dilindungi oleh hukum, dan bahwa

45.

${ }^{3}$ Yan Chai Hum, "Literature Reviews," in SpringerBriefs in Applied Sciences and Technology, 2013, 11-

${ }^{4}$ Andrew S. Denney and Richard Tewksbury, "How to Write a Literature Review," Journal of Criminal Justice Education 24, no. 2 (2013): 218-234.

5Stephanie Garling, "Corpus Delicti," arbeitstitel| Forum für Leipziger Promovierende 3, no. 1 (2011): I-III.

${ }^{6}$ Merriam-Webster Dictionary Online, “Cospus Delicti,” accessed April 26, 2020, https://www.merriamwebster.com/dictionary/corpus delicti. 
kebakaran tersebut diakibatkan oleh tindak pidana beberapa orang. ${ }^{7}$ Alat bukti adalah salah satu terminologi penting di dalam kaidah Corpus Delicti. Dalam kasus pembakaran bangunan misalnya, pembuktian bahwa pembakaran terjadi karena tindak pidana haruslah secara jelas menemukan fakta bahwa kejadian itu bukan terjadi karena sebab alami tetapi kesengajaan. Dengan demikian tersedia dalil untuk disebut bahwa kejahatan telah terjadi. Konsep yang sama juga yang diterapkan pada berbagai bentuk kejahatan lain. Dengan konsep ini, keputusan untuk menyimpulkan kejahatan telah terjadi sangat bergantung pada alat bukti yang tersedia.

Kendati merupakan sebuah fiksi, serial film Crime Scene Investigation (CSI) yang dibuat oleh CBS di Amerika Serikat, dan disaksikan pemirsa Indonesia melalui tayangan satelit, adalah serial yang dibuat berdasarkan konsep Corpus Delicti. Dua hal yang sangat kental muncul di dalam setiap seri film tersebut adalah: pertama, seseorang tidak dinyatakan bersalah hingga orang tersebut dibuktikan bersalah; dan kedua, setiap bukti dapat ditelusuri untuk menemukan pelaku kejahatan yang sebenarnya (follow the evidence). Pembuktian dilakukan melalui teknik forensik modern yang merupakan campuran teknologi alat, metode kerja sistematis, dan logika kriminal pada korban atau lingkungan di sekitar korban. Sehingga, seperti yang selalu muncul di setiap bagian akhir serial ini, muncul efek kejut karena bukti yang ditemukan ternyata mengarah pada pelaku yang tidak diduga sebelumnya.

Serial ini hendak memberikan edukasi bahwa pelaku kejahatan tidak dapat menghindari alat bukti yang ditemukan pada korban oleh tim CSI. Sebaliknya, CSI juga mampu melakukan pembuktian terbalik bahwa seseorang yang semu adisangka sebagai pelaku, pada akhirnya dibebaskan karena alat bukti menguatkannya. Film ini menggambarkan bahwa bukti merupakan material penting di dalam penuntutan sebuah kejahatan. Hal sekecil apapun yang sditemukan di lokasi kejadian, tidak boleh diabaikan dan harus benar-benar dicermati, karena bukti berbicara. Keberadaan serial ini memberi pengaruh yang kuat, khususnya berdampak pada cara berpikir dan pembentukan opini juri di dalam sistem peradilan Amerika Serikat. Penelitian Chin \& Workewych menyimpulkan bahwa serial tersebut memberi beban yang lebih berat pada pundak jaksa di dalam pembuktian kejahatan sehingga seseorang dapat saja dibebaskan dari status bersalah akibat bias yang muncul dalam pandangan juri dengan kehadiran CSI Effect. ${ }^{8}$ Juri menganalisis kejahatan dengan "meminjam" pola pikir para aktor dan logika hukum yang pernah mereka tonton di serial CSI.

Berdasarkan hal tersebut di atas, maka dapat dimengerti bahwa bukti-bukti kejahatan yang ditemukan pada korban atau tempat kejadian perkara, adalah obyek fisik aktual yang memberikan indikasi telah terjadinya kejahatan. Penelusuran tehadap aat bukti tersebut akan mengarahkan penyelidik kepada pelaku kejahatan yang sesungguhnya. Sebagaimana dikatakan oleh Donner-Froelich bahwa bukti dapat menentukan apakah seseorang dapat ditentukan kriminal atau tidak. ${ }^{9}$ Alat bukti tersebut dapat dicari oleh pihak lain melalui temuan Corpus

\footnotetext{
7 John L. Flynn, "Proof of the Corpus Delicti in Arson Cases," The Journal of Criminal Law, Criminology, and Police Science 45, no. 2 (1954): 185.

${ }^{8}$ Jason Chin and Larysa Workewych, "The CSI Effect," SSRN (2016).

${ }^{9}$ Amber Donner-Froelich, "Other Crimes Evidence to Prove the Corpus Delicti of a Child Sexual Offense," University of Miami Law Review 40, no. 1 (1985), https://repository.law.miami.edu/umlr/vol40/iss1/12/.
} 
Delicti di lapangan. Dapat dipahami bahwa istilah Corpus Delicti sangat khas di dalam bidang hukum dan menyangkut pembuktian bahwa sebuah kejahatan telah terjadi.

\section{Pandangan Erastus Sabdono}

Erastus Sabdono adalah seorang teolog dan pemimpin sebuah denominasi gereja di Indonesia. Sebagai teolog dengan latar belakang akademik yang kuat, Sabdono banyak berkiprah menyumbangkan gagasan dan ide-ide baru dalam dunia teologi Indonesia. Seperti Barth dengan tafsiran Kitab Roma ${ }^{10}$, atau Bonhoeffer saat membuat tafsir tentang penciptaan dan dosa di dalam Kejadian ${ }^{11}$, Sabdono mencoba hadir dengan pemikiran kontemporer mengenai kejatuhan Lucifer akibat memimpin pemberontakan di Surga. Konsep teologis yang diusulkannya, merombak dasar penafsiran tradisional yang dianut oleh gereja mainstream dan Sekolah Tinggi Teologia selama ini. Itu sebabnya pemikirannya ini mendapat tanggapan dan reaksi keras berupa penolakan dari banyak kalangan.

Bahkan, sinode Gereja Behtel Indonesia (GBI), tempat Sabdono pernah bernaung, merasa perlu melakukan klarifikasi secara organisasional. Menurut risalah yang dikeluarkan oleh Sinode GBI, rencana Bapa atas manusia bukanlah untuk mengalahkan Iblis karena Yesus telah mengalahkan Iblis. Manusia diciptakan untuk memuliakan Allah (Yes. 43:7) dan bukan untuk membuktikan bahwa Iblis salah. Perdebatan teologis mengenai konstruksi tafsiran kejatuhan Lucifer tersebut, akhirnya berkembang ke ranah pembelaan dogmatif dan menekankan aspek-aspek normatif. Usaha mengkajinya secara teologis menjadi kalah akibat legitimasi tafsiran tradisional dari kalangan mainstream. Dengan kata lain, berbagai komentar dan tanggapan terhadap Sabdono, hasilnya lebih condong pada usaha pembelaan dogmatis daripada kajian objektif-teologis yang terbuka untuk menerima pemikiran baru. Apakah pemikiran Sabdono tersebut?

Dalam bukunya berjudul Corpus Delicti, Sabdono menguraikan pandangannya tentang eksistensi Lucifer yang memimpin pemberontakan melawan Allah. Menurutnya, Lucifer tidak dapat dibinasakan saat itu juga. Menggunakan konsep Corpus Delicti dalam bidang hukum, Sabdono berargumentasi bahwa pada saat itu belum terdapat pembuktian bahwa Lucifer bersalah. ${ }^{12}$ Lucifer tidak lebih dari seorang "anak" yang gagal taat, dan tidak hormat kepada Bapa. Oleh karena itu diperlukan kehadiran anak Allah lainnya yang punya ketaatan dan sikap hormat yang benar kepada Allah Bapa, yakni manusia. Bahkan anak tersebut haruslah memiliki persekutuan erat dengan Bapa secara benar. Eksistensi makhluk yang sesuai tipologi tersebut menjadi "Corpus Delicti”, sehingga Lucifer dan pengikutnya dapat dinyatakan bersalah dan dibungkam selamanya. ${ }^{13}$

Berikut ini disajikan kutipan pemikiran Sabdono di dalam buku tersebut. "Sangat logis kalau dipahami bahwa tidak mungkin Lusifer berani melawan Allah Bapa tanpa alasan yang kuat. Ternyata Lucifer melihat celah peluang atau kemungkinan untuk bisa memenangi perla-

${ }^{10}$ Paul Brazier, "Barth and Rome a Critical Engagement with Catholic Thinkers," The Downside Review 123, no. 431 (2005): 137-152.

${ }^{11}$ Claudia Welz, "Imago Dei: References to the Invisible," Studia Theologica - Nordic Journal of Theology, 2011; Dietrich Bonhoeffer, Creation and Fall: A Theological Exposition of Genesis 1-3, Creation and Fall: A Theological Exposition of Genesis 1-3, 2007.

${ }^{12}$ Erastus Sabdono, Corpus Delicti - Hukum Kehidupan (Jakarta: Rehobot Ministry, 2016), 41-42.

${ }^{13}$ Erastus Sabdono, Lucifer (Jakarta: Rehobot Ministry, 2016), 124. 
wanan terhadap Allah, sebab Allah tidak bertindak diluar hukum keadilanNya. Lucifer mencoba mencari kesempatan untuk mendapat keuntungan dari realitas tersebut. Ia membawa dirinya dengan Allah pada suatu "pertarungan". Lucifer berjudi dengan keputusannya sendiri. Ia berharap bisa memperoleh apa yang diinginkan, yaitu mengangkat diri sebagai penguasa yang menyamai Allah. Itulah sebabnya dikatakan di dalam Yehezkiel 28:16 bahwa ia berdagang. Berdagang artinya melakukan suatu usaha untuk memperoleh keuntungan tetapi masih bersifat spekulatif (untung-untungan). Dimana pun, aktifitas pedagangan memiliki unsur spekulatif seperti ini. Mengapa Allah tidak bisa membinasakan Lucifer saat itu juga ketika ia memberontak? Sebab tindakan Lusifer belum bisa dikatakan salah, selama tidak ada verifikasi atau pembuktian bahwa Lusifer bersalah. Harus ada semacam Corpus Delicti". ${ }^{14}$

Dalam framing kejatuhan iblis, Sabdono melihat bahwa manusia sebagai anak Allah tidak berhenti pada konsep diciptakan segambar dengan bentuk dan rupa Allah. Juga tidak berhenti pada tataran yang menempatkan manusia sebagai mitra Allah di dalam mengelola bumi (dominion mandate). Pemikiran Sabdono melihat lebih jauh dari sekedar fungsi antropologi manusia ketika memandang manusia sebagai pribadi Corpus Delicti. Melaluinya Allah ingin menyatakan bahwa manusia sebagai "anak Allah" telah jauh lebih baik, lebih taat, lebih hormat dan lebih intim kepada Tuhan daripada Lusifer. Dengan kata lain, Sabdono menggali esensi fungsional-rohani manusia yang secara eksistensial dikatakan segambar dan serupa dengan Allah. Posisi eksistensial inilah yang akhirnya menjadi pembuktian bahwa Lucifer bersalah karena "sekarang' sudah tersedia pembanding yang dapat dijadikan acuan/patokan. Logika yang dipakai Sabdono sebenarnya sederhana yakni follow the evidence, bahwa hakikat manusia, bertolak belakang dari Lucifer. Dengan menempatkan manusia sebagai tolok ukur maka kita sebagai orang luar (pembaca) yang melihat cara kerja Tuhan memiliki acuan, pembanding, ukuran, dan alat bukti. Sehingga penciptaan manusia dalam rencana Bapa, salah satunya bertujuan untuk pembuktian yang melegitimasi kebersalahan iblis.

Jika dianalisis lebih dalam, kontroversi yang terjadi akibat pernyataan Sabdono tersebut muncul karena berbenturan dengan klaim kebenaran teologis yang dipegang kuat secara tradisional. Selalu diajarkan bahwa pada akhirnya Lucifer dibuang dari sorga, menjauh dari tahta selamanya, untuk menjalani hukuman akibat pemberontakannya. Persoalannya, di dalam terminologi hukum Corpus Delicti sebagaimana diusung oleh Sabdono, alat bukti yang 'yang membuktikan' tindak kriminalitas Lucifer belum sepenuhnya utuh. Pemakaian beberapa ayat di dalam Alkitab yang menjelaskan perbuatan dan hukuman Lucifer sebagai konsekuensi atas perbuatannya, bukanlah sebuah pembuktian, tetapi merupakan narasi yang mendeskripsikan tindaklanjut pemberontakan. Sebaliknya, menurut beberapa teologi dan pemimpin gereja, kebenaran tradisional yang bertumpu dari narasi Alkitab, sudah cukup membuktikan (Corpus Delicti) mengenai status kriminal Lucifer.

Meskipun terdapat kontras yang sangat tajam, baik pemikiran Sadono maupun kalangan penganut tafsir tradisional, terlihat satu benang merah dari pokok pikiran masing-masing. Kedua pandangan yang berseberangan tersebut mengakui adanya pembuktian atau alat bukti yang cukup relevan untuk pada akhirnya menetapkan tindak kejahatan Lucifer. Terlebih jika

\footnotetext{
${ }^{14}$ Sabdono, Corpus Delicti - Hukum Kehidupan, 41.
} 
dikaitkan dengan kebangkitan Yesus dari kematian, telah hadir semacam legitimasi teologis yang sangat kuat, bahwa iblis pada akhirnya dipermalukan, dilucuti dan dikalahkan.

\section{Konsep Eskatologis Sidang Ilahi}

Sebagai sebuah konsep yang bertitik tolak dari alat bukti dan atau pembuktian, Corpus Delicti yang digagas oleh Sabdono di dalam wacana teologis, membawa angin baru di dalam cara memahami makna eskatologis yang berkaitan dengan sidang ilahi. Corpus Delicti selalu berakhir di persidangan. Namun demikian, mempersepsipkan bahwa sidang hukum di dunia sebagai sesuatu yang sejajar dengan konsepsi sidang ilahi, tidaklah tepat. Sebagaimana dijelaskan pada bagian awal, Corpus Delicti sangat khas sebagai istilah teknis hukum di dalam sistem peradilan dunia. Menggunakan istilah ini di dalam konsepsi sidang ilahi, tidak sama dengan cara kerja petugas CSI melakukan pembuktian. Justru di dalam konsep kekristenan, Tuhanlah yang menjadi CSI-nya. Dia yang memiliki bukti-bukti atas perbuatan Lusifer dan juga perbuatan manusia. Tuhan tidak pernah bertindak menghukum "siapapun" sebelum sebuah pelanggaran terjadi. Justru karena pembuktian atas kejahatan telah terjadi, menjadi dasar bagi tindakan Tuhan memberikan hukuman.

Di dalam konsep eskatologis, terdapat satu sidang pengadilan ilahi yang kelak akan didahapi semua manusia. Perbuatan manusia di dunia menjadi sebuah pembuktian, bahwa sebuah kebaikan atau kejahatan telah terjadi. Semua hal itu dicatat oleh Tuhan sendiri sebagai alat bukti kelak di dalam persidanganNya. Itu sebabnya, Qohelet memberikan peringatan, bahwa "Allah akan membawa setiap perbuatan ke pengadilan yang berlaku atas segala sesuatu yang tersembunyi, entah itu baik, entah itu jahat" (12:14). Kata pengadilan disitu merujuk pada kata mishpat yang berarti tempat untuk melakukan penghakiman, menerima hukuman atau tuntutan. ${ }^{15}$ Ada beberapa konsep kunci yang muncul dari ayat tersebut. Pertama adalah perbuatan. Yang kedua adalah pengadilan, ketiga adalah tersembunyi dan keempat, perbuatan baik dan jahat.

Perbuatan berasal dari kata ibrani kol ma'aseh yang artinya setiap pekerjaan atau perbuatan yang dilakukan oleh manusia (every work). Pengertian ini memberi penekanan bahwa yang dimaksud dengan perbuatan mencakup seluruh hal yang dilakukan oleh manusia tanpa terkecuali. Jika dikaitkan dengan bagian akhir dari kalimat tersebut, maka akan ada dua kelompok perbuatan yakni yang baik dan yang jahat. Dari sini terlihat bahwa pendapat umum selama ini bahwa hanya perbuatan jahat yang di bawa ke pengadilan, dapat digugurkan. Nyatanya, perbuatan baikpun akan diadili. Pengkhotbah memberikan indikator yang sangat penting. Di sana terdapat kata 'tersembunyi' yang dalam konsep Ibrani dikenal sebagai kata ne'lam. The Orthodox Jewish Bible memberikan arti yang sangat khas bahwa ne'lam bukan hanya tidak terlihat tetapi dilakukan diam-diam yang disertai motivasi untuk menyembunyikan perbuatan tersebut. ${ }^{16}$

Jika dipahami, esensi yang mencuat dari nats Pengkhotbah tersebut ada dua. Pertama adalah peringatan untuk menjaga perbuatan dan kepastian bahwa setiap orang akan diadili di hadapan Tuhan. Oleh karena itu, anjuran Lucas diperlukan bahwa selama hidup di dunia ini,

\footnotetext{
${ }^{15}$ James Strong, "A Concise Dictionary of the Words in the Hebrew Bible," in Strong's Exhaustive Concordance of the Bible (Iowa Falls: World Bible Publishers, 1986), 98.

${ }^{16}$ AFII, The Orthodox Jewish Bible, 4th ed. (New Yok: AFI International Publisher, 2011), 721.
} 
setiap orang hendaknya takut akan Tuhan dan tetap menjaga atau hidup menurut perintahperintahNya. ${ }^{17}$ Bahkan menurut Pawson, inti dari seluruh kitab Pengkhotbah disarikan ke dalam konsep takut akan Tuhan. Pawson menulis, Tuhan akan meminta pertanggungan jawab yang diberikanNya kepada kita. ${ }^{18}$ Berarti keberadaan manusia di bumi tidak dapat disamakan dengan konsep pengemudi kendaraan yang melakukan pelanggaran lalu lintas. Eksistensinya sebagai makhluk ciptaan menjadi bagian dari rencana kehidupan yang kelak akan dipertanggung jawabkan kepada Tuhan sebagai sumber dan pemberi kehidupan itu sendiri. Terlebih pada ayat sebelumnya terdapat pernyataan pendahuluan. Pengkhotbah 12:13 menuliskan, "Akhir kata dari segala yang didengar ialah: takutlah akan Allah dan berpeganglah pada perintah-perintah-Nya, karena ini adalah kewajiban setiap orang." Bukan hanya menyangkut kewajiban semua orang tetapi secara literal dalam konsep Ibrani dapat diartikan bahwa itu menyangkut konsep kemanusiaan sebagai bagian dari ciptaan. ${ }^{19}$

Eskatologis Sidang Ilahi merupakan gagasan tentang penghakiman terakhir yang dilakukan oleh Yesus Kristus kepada semua manusia termasuk, dalam konteks martabat ma-nusia itu sendiri. ${ }^{20}$ Itu sebabnya Alter menegaskan bahwa kesalehan dan terlebih kejahatan tidak akan luput dari domain penghakiman Tuhan. ${ }^{21}$ Hal itu merupakan inti dari seluruh pesan Alkitab. Sebagaimana dikatakan Moskala, ajaran Alkitab tentang penghakiman terletak di pusat wahyu Allah. Ini adalah inti dari pesan Alkitabiah yang membuat manusia harus berpikir bahwa selian sebagai Pencipta (Kej. 1-2), Tuhan juga adalah seorang Hakim yang penuh rahmat dan keadilan. Hukuman yang dijatuhkan kepada Adam dan Hawa di taman Eden menjadi bukti awal yang merujuk pada berjalannya sistem pengadilan Tuhan (Kej 3:8-24). ${ }^{22}$ Komentar yang disusun Longman patut menjadi bahan pemikiran untuk men-jawab pertanyaan, apa yang menjadi alasan penghakiman tersebut. Menurutnya, Qohelet atau penulis kitab ini, membawa manusia ke dalam penghakiman untuk dua hal. Yakni memberikan upah kepada orang benar dan hukuman yang adil bagi orang fasik. Longman setuju bahwa penghakiman tersebut berlangsung bukan "saat ini", tetapi di masa depan, sehingga memiliki esensi eskatologis di dalamnya. $^{23}$

Menurut Hoekema, penghakiman berlangsung untuk memenuhi tiga tujuan utama. ${ }^{24}$ Pertama, untuk menyatakan kemahakuasaan Allah dan kemuliaanNya melalui penyingkapan kondisi akhir setiap orang. Kondisi akhir setiap orang masih akan tersembunyi hingga pernghakiman berlangsung. Faktor yang pertama ini lebih terlihat normatif dibanding yang kedua.

\footnotetext{
${ }^{17}$ E C Lucas, “The Bible, Science and Creation," The Evangelical Quarterly 2 (2015): 159.

${ }^{18}$ David Pawson, Unlocking the Bible, 3rd ed. (London: William Collins, 2015), 410.

${ }^{19}$ Bill T. Arnold and Bryan E. Beyer, Encountering the Old Testament (Grand Rapids, MI: Baker Academic, 2015), 308.

${ }^{20}$ Wolf Krötke, "Hope in the Last Judgement and Human Dignity," International Journal of Systematic Theology 2, no. 3 (2000): 270-282.

${ }^{21}$ Robert Alter, The Wisdom Books - Job, Proverbs and Ecclesiastes a Translation with Commentary (New York: W. W. Norton \& Company, 2010).

${ }^{22}$ J Moskala, "Toward a Biblical Theology of God's Judgment: A Celebration of the Cross in Seven Phases of Divine Universal Judgment (An Overview of a Theocentric-Christocentric Approach)," Journal of the Adventist Theological Society 1, no. Spring (2004): 138-162, http://works.bepress.com/cgi/viewcontent.cgi?article=1021\&context=jiri_moskala.

${ }^{23}$ Tremper Longman III, The Book of Ecclesiastes (Grand Rapids, Michigan: Eerdmans, 1998).

${ }^{24}$ Anthony A. Hoekema, "Book Review: Year of Doom," Theology 71, no. 579 (1968): 421-422.
} 
Menurutnya, setiap orang kelak akan menerima upah atau penghukuman menurut perbuatannya masing-masing selama berada di dunia. Penyingkapan elevasi upah akan dinyatakan saat penghakiman. Sedangkan tujuan yang ketiga menyangkut aspek implementasi. Setiap orang akan mengalami eksekusi keadilan Allah di dalam menentukan posisinya pada kekekalan. ${ }^{25}$ Hoekema sependapat dengan maksud Paulus kepada jemaat di Korintus bahwa "kita semua harus menghadap takhta pengadilan Kristus, supaya setiap orang memperoleh apa yang patut diterimanya, sesuai dengan yang dilakukannya dalam hidupnya ini, baik ataupun jahat" (2Kor 5:10). ${ }^{26}$ Walvoord \& Zuck memberi penjelasan tambahan bahwa hal yang dilakukan selama hidup merujuk perbuatan tubuh di dunia yang dianggap sementara. Perbuatan itu tidak berkaitan dengan keselamatan. Nasib kekal seseorang tidak akan ditentukan di kursi penghakiman Kristus. Keselamatan adalah hasil dari iman (Ef. 2: 8-9), tetapi perbuatan yang dikeluarkan dari iman itu (1Tes. 1: 3) yang akan dievaluasi melalui penghakiman. ${ }^{27} \mathrm{Kesim}$ pulannya jelas. Melalui perbuatannya setiap manusia akan dihakimi.

\section{Kesimpulan}

Sidang ilahi dalam eskatologi Kristen adalah sebuah kepastian. Dalam konsep itu tidak ada seorang pun yang luput untuk menghadap tahta penghakiman Tuhan. Dengan kepastian seperti ini maka sebagaimana prinsip Corpus Delicti, dapat dipastikan bahwa Tuhan telah memiliki sejumlah alasan yang tercatat dan akan terus bertambah, untuk membawa setiap orang ke dalam sistem pengadilanNya. Tidak ada alasan bagi setiap manusia untuk menghindari sidang tersebut. Meskipun demikian, terminologi ini tidak dapat sepenuhnya dipakai sebagai sebuah fits biblical expectations dalam teologi Kristen. Perbuatan manusia selama hidup di dunia memang sebuah alat bukti tetapi bukan alat bukti yang semata-mata berpijak pada kejahatan sebagaimana konsep Corpus Delicti. Kekristenan memperluasnya dengan konsepsi perbuatan baik (kebaikan). Istilah Corpus Delicti hanya berpijak pada konsepsi kejahatan. Sementara di dalam sidang pengadilan Ilahi, perbuatan manusia dikategorikan ke dalam dua kelompok, yakni perbuatan jahat dan perbuatan baik. Apabila istilah ini tetap ingin dipertahankan di dalam teologi Kristen, maka pernyataannya haruslah dilengkapi dengan penjelasan tambahan, bahwa Allah tidak akan menjatuhkan hukuman tanpa didahului oleh sebuah pelanggaran atau kesalahan. Jika, pengusiran Lucifer dari sorga adalah sebuah hukuman maka sesungguhnya Tuhan sudah memiliki bukti yang cukup untuk menjatuhkan hukuman tersebut. Jika setiap manusia akan menghadap persidangan ilahi di akhir zaman, maka perbuatannya di dunia akan menjadi bukti-bukti yang menentukan ganjarannya.

${ }^{25}$ Anthony A. Hoekema, Alkitab Dan Akhir Zaman (Surabaya: Penerbit Momentum, 2009), 345.

${ }^{26}$ C. Marvin Pate, Teologi Paulus (Malang: Gandum Mas, 2004), 261.

${ }^{27}$ John F. Walvoord and Roy B. Zuck, The Bible Knowledge Commentary New Testament (Colorado Springs: David C Cook, 1983), 566. 


\section{Referensi}

A., M. Yustia. "Pembuktian Dalam Hukum Pidana Indonesia Terhadap Cyber Crime." Pranata Hukum 5, no. 2 (2010). https://media.neliti.com/media/publications/26724-IDpembuktian-dalam-hukum-pidana-indonesia-terhadap-cyber-crime.pdf.

AFII. The Orthodox Jewish Bible. 4th ed. New Yok: AFI International Publisher, 2011.

Alter, Robert. The Wisdom Books - Job, Proverbs and Ecclesiastes a Translation with Commentary. New York: W. W. Norton \& Company, 2010.

Bill T. Arnold, and Bryan E. Beyer. Encountering the Old Testament. Grand Rapids, MI: Baker Academic, 2015.

Bonhoeffer, Dietrich. Creation and Fall: A Theological Exposition of Genesis 1-3. Creation and Fall: A Theological Exposition of Genesis 1-3, 2007.

Brazier, Paul. "Barth and Rome a Critical Engagement with Catholic Thinkers." The Downside Review 123, no. 431 (2005): 137-152.

Chin, Jason, and Larysa Workewych. "The CSI Effect.” SSRN (2016).

Denney, Andrew S., and Richard Tewksbury. "How to Write a Literature Review." Journal of Criminal Justice Education 24, no. 2 (2013): 218-234.

Dianti, Flora. “Apa Perbedaan Alat Bukti Dengan Barang Bukti?” Hukum Online. Last modified 2011. Accessed April 27, 2020. https://www.hukumonline.com/klinik/detail/ulasan/lt4e8ec99e4d2ae/apa-perbedaanalat-bukti-dengan-barang-bukti-/.

Donner-Froelich, Amber. "Other Crimes Evidence to Prove the Corpus Delicti of a Child Sexual Offense." University of Miami Law Review 40, no. 1 (1985). https://repository.law.miami.edu/umlr/vol40/iss 1/12/.

Flynn, John L. "Proof of the Corpus Delicti in Arson Cases." The Journal of Criminal Law, Criminology, and Police Science 45, no. 2 (1954): 185.

Garling, Stephanie. "Corpus Delicti." arbeitstitel| Forum für Leipziger Promovierende 3, no. 1 (2011): I-III.

Hoekema, Anthony A. Alkitab Dan Akhir Zaman. Surabaya: Penerbit Momentum, 2009.

—. "Book Review: Year of Doom." Theology 71, no. 579 (1968): 421-422.

Hum, Yan Chai. "Literature Reviews." In SpringerBriefs in Applied Sciences and Technology, 11-45, 2013.

III, Tremper Longman. The Book of Ecclesiastes. Grand Rapids, Michigan: Eerdmans Publishing Co., 1998.

Keener, Craig S. The IVP Bible Background Commentary - New Testament. 2nd ed. Downer s Grove, Illionis: IVP Academic, 2014.

Krötke, Wolf. "Hope in the Last Judgement and Human Dignity." International Journal of Systematic Theology 2, no. 3 (2000): 270-282.

Lucas, E C. "The Bible, Science and Creation." The Evangelical Quarterly 2 (2015): 99-113.

Merriam-Webster Dictionary Online. "Cospus Delicti.” Accessed April 26, 2020. https://www.merriam-webster.com/dictionary/corpus delicti.

Moskala, J. "Toward a Biblical Theology of God's Judgment: A Celebration of the Cross in Seven Phases of Divine Universal Judgment (An Overview of a TheocentricChristocentric Approach)." Journal of the Adventist Theological Society 1, no. Spring (2004): 138-162.

http://works.bepress.com/cgi/viewcontent.cgi?article=1021\&context=jiri_moskala.

Pate, C. Marvin. Teologi Paulus. Malang: Gandum Mas, 2004.

Pawson, David. Unlocking the Bible. 3rd ed. London: William Collins, 2015.

Sabdono, Erastus. Corpus Delicti - Hukum Kehidupan. Jakarta: Rehobot Ministry, 2016.

—. Lucifer. Jakarta: Rehobot Ministry, 2016. 
Strong, James. “A Concise Dictionary of the Words in the Hebrew Bible." In Strong's Exhaustive Concordance of the Bible. Iowa Falls: World Bible Publishers, 1986.

Suisno, Suisno. "Peranan Keterangan Saksi Sebagai Salah Satu Alat Bukti Dalam Proses Pidana." Jurnal Independent 4, no. 1 (2016): 66.

Walvoord, John F., and Roy B. Zuck. The Bible Knowledge Commentary New Testament. Colorado Springs: David C Cook, 1983.

Welz, Claudia. "Imago Dei: References to the Invisible." Studia Theologica - Nordic Journal of Theology, 2011. 